\title{
PENGARUH PENGGUNAAN GADGET DAN LINGKUNGAN TEMAN SEBAYA TERHADAP MINAT BELAJAR SISWA KELAS VII PADA MATA PELAJARAN IPS
}

\author{
Mariana Erlin Wasa \\ e-mail: marianawasa@gmail.com \\ Sulistyo \\ e-mail: sulistyo@unikama.ac.id \\ Affan Afian \\ e-mail: affanafian@unikama.ac.id
}

(Program Studi Pendidikan Ekonomi, Fakultas Ekonomika dan Bisnis, Universitas Kanjuruhan, Malang)

\begin{abstract}
Interest in learning is an encouragement that students have to carry out learning activities in order to achieve goals in the learning process. The purpose of this study was to determine the significant and partially simultaneous influence between the use of gadgets and the environment of peers on the learning interest of Grade VII students in Social Sciences subjects at SMP Negeri 17 Malang. this type of research uses ex post facto research using multiple linear regression. This research was conducted in SMP Negeri 17 Malang with a population of 268 students and a sample of 54 students. proportional random sampling technique. Data collection using a questionnaire. Based on the calculation results, it is known that: 1) there is an influence of the use of gadgets and peers' environment on the learning interests of Grade VII students in Social Sciences subjects at SMP Negeri 17 Malang; 17 Malang, 3) there is an influence of peers 'environment in class VII students' social studies interest in Social Sciences at SMP Negeri 17 Malang.
\end{abstract}

Keywords : Gadgets, Peers, Interest in Learning

Abstrak: Minat belajar merupakan dorongan yang dimiliki siswa untuk melakukan kegiatan belajar agar dapat mencapai tujuan dalam proses belajarnya. Tujuan penelitian ini untuk mengetahui pengaruh yang signifikan secara parsial maupun simultan antara penggunaan gadget dan lingkungan teman sebaya terhadap minat belajar siswa kelas VII pada mata pelajaran IPS SMP Negeri 17 Malang. jenis penelitian ini menggunakan penelitian ex post facto dengan menggunakan regresi linier berganda. Penelitian ini dilakukan di SMP Negeri 17 Malang dengan jumlah populasi 268 siswa dan sampel 54 siswa. teknik pengambilan sampel proportional random sampling. Pengumpulan data menggunakan angket. Berdasarkan hasil perhitungan, diketahui bahwa: 1) terdapat pengaruh penggunaan gadget dan lingkungan teman sebaya terhadap minat belajar siswa kelas VII pada mata pelajaran IPS SMP Negeri 17 Malang, 2) terdapat pengaruh penggunaan gadget terhadap minat belajar siswa kelas VII pada mata pelajaran IPS SMP Negeri 17 Malang, 3) terdapat pengaruh lingkungan teman sebaya minat belajar siswa kelas VII pada mata pelajaran IPS SMP Negeri 17 Malang

Kata Kunci : : Gadget, Teman Sebaya, Minat Belajar 


\section{PENDAHULUAN}

Pendidikan merupakan suatu pilar yang sangat penting dalam mencerdaskan kehidupan bangsa. Suatu bangsa yang cerdas dapat meningkatkan pembangunan bangsa. Bangsa yang cerdas dilihat dari pendidikan yang tinggi. Tingkat pendidikan yang tinggi tidak terlepas dari kualitas sumber daya yang dimiliki manusia. Kualitas sumber daya manusia menjadi hal utama dalam pembangunan bangsa, karena jika kualitas sumber daya manusia tinggi, maka akan memudahkan pembangunan bangsa. Jika kualita sumber daya manusia rendah maka akan menghambat pembangunan bangsa.

Kegiatan belajar yang dilakukan baik di sekolah atau di rumah harus berdasarkan minat atau keinginan yang muncul dari dalam diri siswa. Menurut Syah (2011: 151) mengatakan bahwa minat merupakan suatu kecenderungan dan kegairahan yang tinggi atau keinginan yang dimiliki seseorang yang sangat besar terhadap sesuatu. Minat sangat berperan penting dalam kegiatan belajar peserta didik. Menurut Rusmiati (2017) mengatakan bahwa minat adalah perasaan yang dapat mendorong seseorang dalam melaksanakan suatu kegiatan atau dorongan yang melatarbelakangi seseorang dalam melakukan sesuatu.

Perkembangan teknologi saat ini telah mengalami kemajuan dengan sangat pesat, hal ini ditandai dengan munculnya berbagai macam alat teknologi salah satunya adalah gadget. Gadget adalah sebuah istilah yang berasal dari bahasa inggris, yang artinya perangkat elektronik kecil yang memiliki fungsi yang lebih khusus (Winarno, 2009). Zaman sekarang ini di seluruh dunia sudah memiliki dan menggunakan gadget. Bahkan satu orang saja memiliki lebih dari satu gadget. Penggunaan gadget untuk sekarang ini tidak hanya dimiliki oleh para pejabat atau yang sudah bekerja, akan tetapi gadget sekarang sudah dimiliki hampir seluruh kalangan tidak terlepas dari para pelajar. Kemajuan teknologi dalam dunia pendidikan sangat membantu. Tersedianya fasilitas yang terdapat pada media sosial dapat digunakan untuk mencari informasi yang dibutuhkan dengan mudah, cepat dan praktis. Adanya penggunaan gadget yang di dalamnya terdapat fasilitas koneksi internet, dengan ini siswa memanfaatkannya untuk mengakses informasi yang berkaitan dengan pelajaran.

Menurut Anggraeni (2018) dalam hasil penelitiannya mengatakan bahwa gadget sangat berperan penting dalam kehidupan manusia sebagai alat untuk berkomunikasi, memperbanyak relasi, menambah wawasan , pengetahuan, pendidikan dan bisnis. Akan tetapi, di sisi lain, terdapat hal yang berlawanan yang disebabkan dari faktor keteledoran pemakainya atau kekurangtepatan dalam memanfaatkan fungsi yang sebenarnya. Hal ini diungkapkan juga oleh Harfiyanto, Utomo, \& Budi (2015) dalam penelitian mengatakan bahwa dalam pengaruh handphone siswa menjadi lebih mengandalkan handphone daripada belajar. Hubungan dengan teman sebaya memiliki arti yang sangat penting bagi kehidupan remaja. Melalui hubungan teman sebaya, anak dan remaja belajar tentang hubungan timbal balik yang teratur (Desmita, 2011: 230). Remaja juga mulai mengekspresikan perasaan dirinya dengan cara lebih matang dan berusaha memperoleh kebebasan emosional dengan cara menggabungkan diri dengan teman sebaya. Teman sebaya juga memiliki peran dalam perkembangan belajar remaja. Hal ini juga diungkapkan oleh Anggraini (2014) mengatakan bahwa melalui pertemuan kontak di dalam sekolah yang rutin, baik secara sadar atau tidak sadar siswa mulai belajar dan mengembangkan minat serta motivasi dalam dirinya yang didapatkan dari kelompok sosial sebaya di sekolah. Interaksi dengan teman sebaya dari kebanyakan anak usia sekolah ini terjadi dalam bentuk grup atau kelompok, sehingga periode ini sering disebut usia kelompok (Desmita, 2011). Berkumpul dengan teman sebaya yang memiliki kesamaan dalam berbagai hal ini, tentu dapat menjadi salah satu cara dimana 
remaja dapat mengubah kebiasaan hidupnya dan mencoba sesuatu hal yang baru dan mampu saling mendukung satu sama lain.

Penggunaan gadget di SMP Negeri 17 Malang, siswa hanya diperkenakan menggunakan gadget diluar jam pelajaran. Siswa akan menggunakan gadget ketika diperintahkan oleh bapak dan ibu guru. Namun, siswa kadang kurangketepatan memanfaatkan gadget saat jam beristirahat. Siswa lebih memilih untuk bermain game ketimbang mencari pelajaran untuk materi pelajaran berikutnya. Selama pembelajaran siswa juga berusaha untuk memainkan gadgetnya. Terkait pergaulan kelompok teman sebaya, masih ada siswa yang berbicara dengan teman sebangkunya terlebih saat diskusi berlangsung. dengan teman sebangkunya terlebih saat diskusi berlangsung. Ketika disuruh untuk mengerjakan tugas yang diberikan oleh guru, masih ada beberapa siswa yang belum langsung mengerjakan tugas yang diberikan, siswa akan mengerjakan ketika teman sebangkunya sudah selesai mengerjakan. Ini menandakan bahwa penggunaan gadget dan teman sebaya memiliki pengaruh yang besar terhadap minat belajar IPS.

Penggunaan gadget di SMP Negeri 17 Malang, siswa hanya di ijinkan menggunakan gadget diluar jam pelajaran. Siswa akan menggunakan gadget ketika diperintahkan oleh bapak dan ibu guru. Namun, siswa kadang kurangketepatan memanfaatkan gadget saat jam beristirahat. Siswa lebih memilih untuk bermain game ketimbang mencari pelajaran untuk materi pelajaran berikutnya. Selama pembelajaran siswa juga berusaha untuk memainkan gadgetnya. Terkait pergaulan kelompok teman sebaya, masih ada siswa yang berbicara dengan teman sebangkunya terlebih saat diskusi berlangsung. Ketika disuruh untuk mengerjakan tugas yang diberikan oleh guru, masih ada beberapa siswa yang belum langsung mengerjakan tugas yang diberikan, siswa akan mengerjakan ketika teman sebangkunya sudah selesai mengerjakan. Ini menandakan bahwa penggunaan gadget dan teman sebaya memiliki pengaruh yang besar terhadap minat belajar IPS.

Berdasarkan uraian di atas, tujuan penelitian ini adalah untuk mengetahui apakah ada pengaruh secara simultan dan parsial antara penggunaan gadget dan lingkungan teman sebaya terhadap minat belajar siswa kelas VII pada mata pelajaran IPS SMP Negeri 17 Malang

\section{METODE}

Rancangan penelitian yang digunakan dalam penelitian ini adalah penelitian kuantitatif. Jenis penilitian ini menggunakan penelitian ex post facto. Variabel bebas dalam penelitian ini adalah penggunaan gadget (X1) dan lingkungan teman sebaya (X2) sedangkan variable terikat adalah minat belajar (Y). Populasi dalam penelitian ini adalah siswa kelas VII SMP Negeri 17 Malang yang berjumlah 268 siswa. Dasar pengambilan sampel dalam penelitian ini menurut Arikunto (2010) mengatakan jika populasi kurang dari 100 maka pengambilan sampel semuanya. Jika populasi lebih dari 100 maka diambil $10-15 \%$ atau $20-25 \%$ atau lebih. Maka sampel yang diambil sebesar 54 siswa. Pengambilan sampel dalam penelitian ini menggunakan teknik sampel proportional random sampilng.

Instrumen dalam penelitian ini menggunakan angket yang terdiri dari beberapa pernyataan. Angket dalam penelitian ini menggunakan skala likert dengan opsi jawaban sangat setuju (SS), setuju (S), kurang setuju (KS), tidak setuju (TS) dan sangat tidak setuju (STS). Data primer dalam penelitian ini diperoleh dari hasil pengisian angket variabel penelitian yaitu penggunaan gadget, lingkungan teman sebaya dan minat belajar sedangkan data sekunder dalam penelitian ini yaitu hasil dokumentasi. Analisis data dalam penelitian ini menggunakan uji asumsi klasik, analisis regresi berganda dan pengujian hipotesis. Pengujian uji asumsi klasik dalam penelitian ini menggunakan uji normalitas, uji multikolinieritas, uji heteroskedastisitas dan uji autokorelasi. Uji hipotesis dalam penelitian ini menggunakan uji F, uji t dan uji R2. Dalam penelitian ini, agar data yang diperoleh akurat, peneliti menggunakan bantuan program SPSS For Windows Versi 22. 


\section{PEMBAHASAN}

Pengaruh Penggunaan Gadget dan Lingkungan Teman Sebaya Terhadap Minat Belajar Siswa Kelas VII Pada Mata Pelajaran IPS SMP Negeri 17 Malang.

Hasil penelitian ini menunjukan bahwa adanya pengaruh penggunaan gadget dan lingkungan teman sebaya terhadap minat belajar siswa kelas VII pada mata pelajaran IPS SMP Negeri 17 Malang. Hal ini berarti, penggunaan gadget dan lingkungan teman sebaya memberikan kontribusi yang baik terhadap minat belajar siswa. Dalam penelitian yang dilakukan oleh Sirait (2016), mengatakan bahwa untuk mengatasi siswa yang kurang berminat dalam belajar, guru hendaknya dapat menciptakan suatu kondisi tertentu seperti dapat mengembangkan variasi dalam mengajar. Dengan variasi ini, siswa akan merasa senang dan memperoleh kepuasan terhadap belajar. Salah satunya adalah tersedianya prasarana dan sarana dalam kegiatan belajar siswa khususnya tersedianya penggunaan teknologi.

Menurut Sukarno \& Hardinto (2018) dalam penelitiannya tentang penggunaan gadget mengatakan bahwa adanya penggunaan gadget yang didalamnya tersedia fasilitas koneksi internet, siswa dapat memanfaatkan koneksi internet tersebut untuk mengakses berbagai macam informasi dan referensi yang berkaitan dengan pelajaran. Pernyataan ini sejalan dengan pendapat dari Rachmawati (2017) dalam penelitiannya tentang pengaruh penggunaan gadget, mengatakan bahwa gadget dapat dimanfaatkan untuk mencari informasi, sebagai media belajar dan sebagai sarana untuk mengembangkan materi pelajaran.

Selain dari penggunaan gadget, minat belajar siswa kelas VII SMP Negeri 17 Malang juga dipengaruhi oleh lingkungan teman sebaya. Sejalan dengan pendapat Desmita (2012), yang mengatakan bahwa dukungan teman sebaya juga memiliki peran dalam perkembangan belajar remaja, sehingga dengan siapa dan dimana remaja berteman bisa berpengaruh terhadap minat belajar yang dapat dimiliki remaja. Berkumpul dengan teman sebaya yang memiliki kesamaan dalam berbagai hal, dapat menjadi salah satu cara bagi remaja agar dapat mengubah kebiasaan hidupnya dan mencoba berbagai hal yang baru serta saling mendukung satu sama lain. Hal ini juga sependapat dengan hasil penelitian yang dilakukan oleh Radhika (2016) yang mengatakan bahwa teman sebaya anak yang ada di sekolah maupun dalam lingkungan tempat tinggal dapat mempengaruhi perilaku anak, persepsi anak terhadap belajar di sekolah dan yang paling penting adalah mempengaruhi hasil belajar siswa.

Berdasarkan hasil penelitian penggunaan gadget dan lingkungan teman sebaya siswa kelas VII SMP Negeri 17 Malang baik, ini diperoleh dari jawaban responden siswa kelas VII. Siswa sudah dapat memanfaatkan gadget dengan baik sebagai sumber informasi, sebagai alat komunikasi, sebagai media belajar dan penggunaan internet untuk mengakses materi pelajaran. Lingkungan teman sebaya juga memberikan peran dalam perkembangan belajar remaja, yaitu dengan cara membentuk kelompok untuk belajar bersama, saling berbagi masalah dan kesulitan yang dialami, keterlibatan individu dalam berinterkasi, menjadi teman belajar siswa dan menemukan harga diri siswa.

\section{Pengaruh Penggunaan Gadget Terhadap Minat Belajar Siswa Kelas VII Pada Mata Pelajaran IPS SMP Negeri 17 Malang}

Hasil penelitian ini dapat diketahui bahwa terdapat pengaruh yang signifikan antara penggunaan gadget terhadap minat belajar siswa kelas VII pada mata pelajaran IPS SMP Negeri 17 Malang. Hal ini menunjukan bahwa penggunaan gadget memberikan manfaat bagi proses pembelajaran siswa. Sejalan dengan pendapat dari Anggraeni (2018) dalam penelitiannya tentang pengaruh penggunaan gadget mengatakan bahwa gadget saat ini tidak hanya dijadikan sebagai alat komunikasi, akan tetapi juga dapat dipergunakan sebagai multimedia dan salah satunya bisa dimanfaatkan dalam dunia pendidikan.

Menurut penelitian yang dilakukan Laili (2017), dalam penelitiannya mengatakan bahwa gadget adalah perangkat eletronik kecil yang memiliki fungsi khusus untuk mengunduh informasi 
terbaru dengan teknologi yang baru untuk membuat hidup lebih praktis. Era digital ini, siswa bisa belajar melalui berbagai media elektronik tidak terbatas pada buku pegangan saja. Sukarno \& Hardinto (2018) dalam penelitiannya tentang penggunaan gadget mengatakan bahwa sumber belajar yang dimiliki siswa tidak hanya berasal dari buku saja, akan tetapi dengan fasilitas akses internet yang terdapat pada gadget, siswa bisa memanfaatkan untuk mendapatkan e-book atau informasi seputar update perkembangan ekonomi terkini sehingga pengetahuan siswa bisa lebih luas.

Hal ini juga didukung oleh pendapat Syamsul (2015) yang mengatakan bahwa perkembangan teknologi hendaknya dapat dimanfaatkan dengan sebaik mungkin, dengan demikian siswa belajar tidak hanya terbatas pada buku pegangan, akan tetapi siswa dapat belajar dengan memanfaatkan jaringan internet untuk mendapatkan e-book secara gratis guna mendukung proses pembelajaran.

Berdasarkan hasil penelitian yang telah dilakukan, diperoleh jawaban dari responden yang mengungkapkan bahwa penggunaan gadget dapat mendukung siswa dalam proses pembelajaran. Siswa dapat memanfaatkan gadget sebagai sumber informasi. Memanfaatkan koneksi internet untuk mengakses berbagai macam informasi dan referensi yang berkaitan dengan mata pelajaran. Siswa dapat memanfaatkan gadget sebagai alat komunikasi. Gadget dapat dijadikan sebagai media belajar. Seperti menyimpan materi pelajaran dalam bentuk pdf, word, powerpoint. Karena dengan gadget, siswa akan belajar kapan dan dimana saja, tidak hanya dalam ruangan. Dalam penggunaan gadget berkaitan dengan lama penggunaanya, hampir seluruh siswa masih memiliki batas wajar dalam hal menggunakannya.

Penerapan penggunaan teknologi pada bidang pendidikan sekarang ini tidak bisa dihindari. Tuntutan global masa sekarang ini, menuntut dunia pendidikan untuk selalu dan senantiasa menyesuaikan perkembangan teknologi terhadap usaha dalam peningkatan mutu pendidikan. Siswa dapat menempatkan dengan baik dan bijak dalam menggunakan gadget. Sehingga dari menggunakan gadget tersebut dapat memberikan pengaruh yang poisitf terhadap minat belajar siswa.

\section{Pengaruh Lingkungan Teman Sebaya Terhadap Minat Belajar Siswa Kelas VII Pada Mata Pelajaran IPS SMP Negeri 17 Malang}

Hasil penelitian dapat diketahui bahwa terdapat pengaruh lingkungan teman sebaya terhadap minat belajar siswa kelas VII pada mata pelajaran IPS SMP Negeri 17 Malang. Artinya lingkungan teman sebaya memberikan pengaruh dan peran yang penting dalam perkembangan belajar siswa. Kedekatan dan keakraban dengan teman sebaya yang kuat dan terjalin dengan baik maka akan membentuk suatu kelompok, suatu ikatan yang sangat erat. Penelitian ini diperkuat dengan pendapat yang dikemukakan oleh Haryanta \& Sujatmiko (2012: 259) yang mengatakan bahwa teman sepermainan adalah kelompok sosial dalam jumlah kecil yang memiliki kesamaan usia, memiliki kesamaan kegiatan, biasanya dalam kelompok ini mempunyai tujuan yang sama yaitu mencari penghiburan dan kepuasan rohani. Berkumpul dengan teman sebaya yang memiliki kesamaan dalam berbagai hal tertentu menjadi salah satu cara agar remaja dapat mengubah kebiasaan hidupnya dan memcoba berbagai hal baru serta saling mendukung satu sama lain. Sejalan dengan hasil penelitian yang dilakukan oleh Putri (2017), mengatakan bahwa teman sebaya bagi remaja menjadi salah satu pemberi dukungan pada setiap hal yang akan dilakukan, memutuskan suatu perihal, maupun hal yang ingin dicapai, sehingga teman sebaya menjadi salah satu pemberi dukungan sosial yang penting bagi remaja. Penelitian tentang pengaruh teman sebaya juga dilakukan oleh Korir (2014), hasil penelitiannya menunjukan bahwa lngkungan sekolah dan pengaruh teman sebaya siswa memberikan kontribusi terhadap akademik kinerja siswa di Kabupaten Vihiga, Kenya.

Melalui interaksi dan keterlibatan siswa di dalam lingkungan sekolah yang rutin, baik secara sadar maupun tidak sadar, siswa mulai belajar dan mengembangkan minat serta motivasi dalam dirinya yang didapatkan dari kelompok sosial sebaya di sekolah. Hal ini, minat dapat dipengaruhi 
oleh peranan teman sebaya siswa, pernyataan ini sesuai dengan penelitian yang dilakukan oleh Anggraini (2014) yang mengatakan bahwa semakin baik pergaulan teman sebaya pada remaja maka akan semakin tinggi minat dan motivasi dalam belajar serta hasil belajar siswa. Jika remaja berteman dengan remaja yang memiliki minat belajar yang tinggi, maka akan tinggi pula minat belajar remaja tersebut.

Penerapan lingkungan teman sebaya diantara siswa sudah berjalan dengan baik di SMP Negeri 17 Malang. Jawaban dari responden menunjukan bahwa, siswa merasa senang dan nyaman dengan adanya pertemanan yang dimilikinya. Melalui hubungan teman sebaya, siswa dapat saling bertukar pendapat mengenai materi pelajaran dan berbagai masalah. Adanya saling terbuka dalam berteman, siswa secara tidak langsung mendapatkan dukungan dari temannya. Siswa merasa adanya dorongan dan dukungan untuk belajar dan mengerjakan tugas bersam-sama. Siswa dapat menjadikan teman untuk belajar seperti membentuk kelompok belajar di sekolah maupun di rumah. Siswa dapat bertanya kepada temannya ketika mengalami kesulitan dalam menyelesaikan tugas dari bapak ibu guru.

\section{KESIMPULAN}

Berdasarkan hasil analisis yang telah dilakukan oleh peneliti dan pembahasan yang telah diuraikan maka dapat diambil kesimpulan, yaitu: 1) terdapat pengaruh yang signifikan secara simultan antara penggunaan gadget dan lingkungan teman sebaya terhadap minat belajar siswa kelas VII pada mata pelajaran IPS SMP Negeri 17 Malang; 2) terdapat pengaruh yang signifikan secara parsial antara penggunaan gadget terhadap minat belajar siswa kelas VII pada mata pelajaran IPS SMP Negeri 17 Malang; 3) terdapat pengaruh yang signifikan secara parsial antara lingkungan teman sebaya terhadap minat belajar siswa kelas VII pada mata pelajaran IPS SMP Negeri 17 Malang.

\section{DAFTAR PUSTAKA}

Anggraeni, A. (2018). Pengaruh Penggunaan Gadget Terhadap Kehidupan Sosial Para SiswaSMA. Jurnal PPKn \& Hukum, 13(1), 64-76.

Anggraini, E. (2014). Pengaruh Pergaulan Teman Sebaya dan Motivasi Belajar Terhadap Hasil Belajar Ekonomi Siswa Kelas XI IPS SMA Negeri 9 Sukodono Tahun Ajaran 2013/2014. Jurnal Publikasi.

Desmita. (2011). Psikologi Perkembangan Peserta Didik. Bandung: Pt. Remaja Rosdakarya.

Harfiyanto, D., Utomo, C. B., \& Budi, T. (2015). Pola Interaksi Sosial Siswa Penggunaan Gadget Di SMA N 1 Semarang. Journal of Educational Social Studies, 4(1),1-5. http://journal.unnes.ac.id/sju/index.p hp/jess

Haryanta, A., \& Sujatmiko, E. (2012). Kamus Sosiologi. Surakarta: Aksara Sinergi Media.

Korir, D. K. (2014). The Impact of School Environment and Peer Influences on Students Academic Performance in Vihiga County, Kenya. International Journal of Advanced Research (IJAR), 2(2), 1-12.

Laili, U. (2017). Influence Of Gadget On Social Personal Of Early Childhood. Surabaya International Health Conference, 1, 273-277.

Putri, A. F. E. (2017). Pengaruh Dukungan Sosial Teman Sebaya Terhadap Minat Belajar Siswa Kelas XI Di Sma Negeri 1 Mojo Kabupaten Kediri Tahun Ajaran 2016. Artikel Skripsi.

Radhika. (2016). Pengaruh Lingkungan Teman Sebaya, Kecanduan Game Online dan Perhatian Orang Tua Terhadap Hasil Belajar Ekonomi Siswa Kelas XI IPS Di SMA Negeri 9 Padang. E-Jurnal.

Rusmiati. (2017). Pengaruh Minat Belajar Terhadap Prestasi Belajar Bidang Studi Ekonomi Siswa Al Fattah Sumbermulyo. Jurnal Ilmiah Pendidikan Dan Ekonomi, 1(1), 21-36. 
Sirait, E. D. (2016). Pengaruh Minat Belajar Terhadap Prestasi Belajar Matematika. Jurnal Formatif, 6(1), $35-43$.

Sukarno, Z. A., \& Hardinto, P. (2018). Pengaruh Penggunaan Gadget, Minat Belajar Dan Kecerdasan Emosional Terhadap Hasil Belajar Siswa Kelas XI IS Pada Mata Pelajaran Ekonomi Di Sman 1 Kepanjen. Jurnal Pendidikan Ekonomi, 11(1), 9-19 https://doi.org/https://dx.doi.org/10.17 977/UM014v11i12018p009

Syah, M. (2011). Psikologi Belajar. Jakarta: Pt.Raja Grafindo Persada.

Syamsul, A. (2015). Gadget Smartphone Utility and Learning Facility on Economic Learning Achievement. www.academia.edu/28680397/GADGET SMARTPHONE

Winarno, W. (2009). Panduan Penggunaan Gadget. Jakarta: Pt. Rineka Cipta 